\title{
Hemoglobin-A-lc-szint-mérés: analitikai vonatkozások és ezek jelentősége a klinikai döntéshozatalban
}

\author{
Vásárhelyi Barna dr. \\ Semmelweis Egyetem, Általános Orvostudományi Kar, Laboratóriumi Medicina Intézet, Budapest
}

\begin{abstract}
A diabeteses betegek gondozása, állapotuk monitorozása napjainkban nem képzelhető el hemoglobin-A-1c-szint rendszeres meghatározása nélkül. A hemoglobin-A-lc ezenkívül bizonyos feltételek mellett a diabetes diagnosztikájában is segíthet. Az áttekintő közlemény röviden ismerteti a hemoglobin-A-lc-szint meghatározására használt módszerek fóbb típusait és az ezekkel nyert eredményeket befolyásoló állapotokat. Bemutatja a terápiás döntéshozatalhoz fontos hemoglobin-A-lc-szint vágóértékeit is. A különböző eszközökkel különböző laboratóriumokban mért eredmények napjainkban, a standardizációs törekvéseknek köszönhetően, összehasonlíthatók, klinikai döntéshozatalra használhatók. A hemoglobin-A-lc-szintet különösen kritikusan kell értékelni haemoglobinopathiában szenvedő betegeknél, illetve azoknál, akiknél a vörösvérsejtek átlagos életideje megváltozik. Orv. Hetil., 2016, 157(19), $753-757$.
\end{abstract}

Kulcsszavak: cukorbetegség szövődménye, klinikai laboratóriumi módszerek, hemoglobin-A, glikált

\section{Measurement of hemoglobin Alc: analytical principles and their significance in clinical decision making}

\begin{abstract}
Appropriate care and monitoring of the condition of patients with diabetes is indispensable from the regular measurement of hemoglobin Alc levels. Under well defined criteria hemoglobin Alc levels may also support the diagnosis of diabetes. This review provides a short description of the major principles of methods used for hemoglobin Alc determination and it reviews conditions interfering with the results. It also presents cut-off values for therapeutic decision making. As the results of world-wide efforts for standardization of hemoglobin Alc values obtained with different tests in different laboratories, the hemoglobin Alc results are comparable and can be used for clinical decisions. However, hemoglobin Alc should be considered with a particular caution in patients with hemoglobinopathies and in those with conditions affecting the average life-time of red cells.
\end{abstract}

Keywords: diabetes complications, clinical laboratory techniques, hemoglobin A, glycosylated

Vásárbelyi, B. [Measurement of hemoglobin Alc: analytical principles and their significance in clinical decision making]. Orv. Hetil., 2016, 157(19), 753-757.

(Beérkezett: 2016. február 4.; elfogadva: 2016. február 25.)

\section{Rövidítések}

$\mathrm{HbA}_{\mathrm{lc}}=$ hemoglobin-A-lc; POCT = betegágy mellett használható eszköz

Magas glükózszint esetén a szervezetben a különböző molekulákra, fehérjékre cukor rakódik. A glikációnak nevezett folyamat eredményeként megváltozhat a sejtek múködése. Ez hosszú távon szövődményekhez vezet.
A glükózszint arányában zajló glikációs folyamat becslésére a hemoglobin-A-lc- $\left(\mathrm{HbA}_{\mathrm{lc}^{-}}\right)$szint meghatározását használják. Egy nagy klinikai vizsgálat, a Diabetes Control and Complications Trial során 1441, 1-es típusú diabeteses beteg bevonásával értékelték a $\mathrm{HbA}_{\mathrm{lc}_{\mathrm{c}}}$-szint és a microvascularis szövődmények kapcsolatát, és kiderült: a $\mathrm{HbA}_{\mathrm{lc}}$-érték minden 1\%-os emelkedése a későbbi retinopathia kockázatának 2,26-szoros, a nephropathia kockázatának 1,80-szeres emelkedésével jár [1]. Ezenkívül 
alkalmas lehet annak a becslésére, hogy mennyire volt hatékony a glykaemiás kontroll az elmúlt 3 hónap során; illetve az újabb felmérések alapján nem diabeteses személynél akár a későbbi diabetes kockázatára vonatkozóan is adhat információt. A $\mathrm{HbA}_{\mathrm{lc}}$-mérés elvégeztetéséhez és az eredmények értékeléséhez nem árt azonban néhány dologgal tisztában lenni.

\section{Mit is mérnek voltaképp?}

A vörösvérsejtekben levő hemoglobinmolekulákat 4 lánc ( 2 alfa- és 2 béta-lánc) alkotja. A HbA $\mathrm{lc}_{\mathrm{c}}$ a Maillard-reakció eredményeként alakul ki: a béta-lánc terminális valinja a glükózzal reagálva aldimidet képez (ez a Schiff-bázis vagy labilis $\mathrm{HbA}_{\mathrm{lc}}$ ), ami egy átrendeződés során stabil ketoaminná $\left(\mathrm{HbA}_{\mathrm{lc}}\right)$ alakul. Ez a reakció azonban nem egyedi: a hemoglobinmolekula legalább 10 másik pontján is bekövetkezhet, amelynek eredményeként egyéb glikált hemoglobinok is kialakulnak [2]. Az összes glikált hemoglobin mintegy $60 \%$-át teszi ki a $\mathrm{HbA}_{\mathrm{lc}}$. A glükóz mellett más molekulák, elsősorban karbamid is kapcsolódhat a hemoglobinban levő aminosavakhoz; ezt karbamilált hemoglobinnak nevezik.

A hemoglobin glikációját természetesen alapvetően befolyásolja a szerkezete. A szerkezetet megváltoztató pontmutációk eredményeként kialakuló hemoglobinvariánsok másutt glikálódnak, ezért hemoglobinvariánsok jelenléte esetén a $\mathrm{HbA}_{\mathrm{lc}}$ aránya is változik. Összességében a $\mathrm{HbA}_{\mathrm{lc}}$ a glikált hemoglobinok nagyobb csoportjának csupán egy tagja.

\section{Hogyan mérik?}

A vizsgálat teljes (EDTA-val alvadásgátolt) vérből történik. Egy meghatározáshoz néhány mikroliter vér elegendő. Vannak olyan, betegágy mellett használható (POCT) eszközök, amelyeknél kapilláris vércseppből történik a mérés. A $\mathrm{HbA}_{\mathrm{lc}}$ stabil: az 1 héten át $2-8{ }^{\circ} \mathrm{C}$-on tárolt mintában sem változik a mért érték. A meghatározáshoz a minta a többi mintával együtt küldhető a laboratóriumba.

A laboratóriumban hemolizált mintát használnak. A $\mathrm{HbA}_{\mathrm{lc}}$ mérésére aktuálisan több mint 100-féle mérési módszer érhető el. Ezeket két fő csoportra osztják [3].

\section{Szeparációs módszerek}

A $\mathrm{HbA}_{\mathrm{lc}}$ és a nem glikált Hb kémiai tulajdonságai eltérőek. Ennek alapján lehet elválasztástechnikával a hemoglobinfrakciókat elkülöníteni és a $\mathrm{HbA}_{\mathrm{lc}}$ relatív arányát meghatározni. Elválasztástechnikát alkalmaznak az alábbi eljárások:

a) Ioncserélő kromatográfia: $\mathrm{A} \mathrm{HbA}_{\mathrm{lc}}$ és a Hb pI-értéke kismértékben eltér. A $\mathrm{HbA}_{\mathrm{lc}}$ és a $\mathrm{Hb}$ elkülönítése ennek alapján - HPLC eszköz segítségével - lehetséges. Az ioncserélő kromatográfia segítségével a magzati $\mathrm{Hb}$ (HBF), a karbamilált HbA és a kóros Hb-variánsok jól elkülöníthetők. b) Kapilláris elektroforézis: Ez az eljárás a $\mathrm{HbA}_{\mathrm{lc}}$ és egyéb Hb-frakciók töltéskülönbségén alapul. A szeparáció nagyfeszültségü elektromos mezőben és elektroozmotikus áramlás alapján történik.

c) Affinitáskromatográfia: A boronsavval fedett gyöngyöket tartalmazó oszlopon a nem glikált $\mathrm{Hb}$ szabadon átjut, míg a $\mathrm{HbA}_{\mathrm{lc}}$ az oszlopon retineálódik. A $\mathrm{HbA}_{\mathrm{lc}}$ mellett a többi glikált $\mathrm{Hb}$ is retineálódhat az oszlopon. (A Hb-hez mintegy 15 más ponton is tud glükóz kapcsolódni.) Az egyes glikált Hb-altípusok (amelyek az öszszes glikált $\mathrm{Hb}$ közel felét teszik ki) a $\mathrm{HbA}_{1 \mathrm{c}}$-vel arányosan keletkeznek.

\section{Kémiai automatán alkalmazott módszerek}

A kémiai automatákon alkalmazott tesztek során a $\mathrm{HbA}_{\mathrm{lc}}$-koncentrációt egy, a glikált $\mathrm{N}$-terminális valinre specifikus reakció alapján határozzák meg. Az ebbe a csoportba tartozó eljárások során minden esetben két tesztre van szükség a $\mathrm{HbA}_{\mathrm{lc}}$-koncentráció méréséhez: a mérések során a $\mathrm{HbA}_{\mathrm{lc}}$ mellett az összhemoglobinszintet is meghatározzák fényelnyelés alapján. (A két független teszt pontatlansága összeadódik, ezért a kémiai módszerek pontatlansága nagyobb a szeparációs módszerekénél.) Ezek a módszerek két nagyobb csoportra oszthatók:

a) Immunoassay-k: Az immunoassay-k során feleslegben anti- $\mathrm{HbA}_{\mathrm{lc}}$ ellenanyagot adnak a hemolizált mintához. A $\mathrm{HbA}_{\mathrm{lc}}$ kötődése után a feleslegben levő ellenanyagok agglutinálnak. A készülék a keletkező immunkomplexek turbiditását határozza meg.

b) Enzimatikus módszerek: A reagensben levő proteáz a béta-láncot hasítja és ennek eredményeként döntően dipeptidek keletkeznek. Az ezt követően hozzáadott fruktozil-peptid-oxidáz enzim a $\mathrm{HbA}_{\mathrm{lc}}$-ben levő glikált aminosavakkal reagálva hidrogén-peroxidot termel, amelynek mennyiségét további segédenzimek hozzáadásával lehet meghatározni.

A különböző $\mathrm{HbA}_{1 \mathrm{c}}$-mérések pontossága eltérő lehet. Napjainkban bármelyik elfogadható, amennyiben a mérések során két feltétel teljesül. (Ez vonatkozik a betegágy mellett végzett mérésekre is.) (1) Megfelelően standardizált referenciaanyagra visszavezethető a mérés. (2) Megfelelő a minőségbiztosítási rendszer, azaz rendszeresen kontrollálják az eszköz múködését. Ez belső és külső minőség-ellenőrzési programokban való részvételt jelent. Ennek részeként ismert $\mathrm{HbA}_{\mathrm{lc}}$-kontrollanyagok $\mathrm{HbA}_{\mathrm{lc}}$-szintjét kell meghatározni a mérések során, illetve - adott időközönként - a mérést végző számára nem ismert szintű, egy központi szervezet által kiküldött anyagokat kell meghatározni.

\section{Mit jelent az eredmény?}

A $\mathrm{HbA}_{\mathrm{lc}}$ mért értéke módszerfüggő: a különböző technikák ugyanabból a mintából eltérő eredményeket adnak. Ezért az egyes (eltérô módszereket alkalmazó) kli- 
nikai vizsgálatok eredményeit sem lehetett összevetni, egységes irányelveket kidolgozni. Annak érdekében, hogy az eredmények egységesek legyenek, egy referenciaanyag kidolgozására volt szükség. Ismert mennyiségú $\mathrm{HbA}_{\mathrm{lc}}$ és nem glikált $\mathrm{Hb}$-t $\left(\mathrm{HbA}_{0}\right)$ kevertek össze és ez alapján kalibrálták be a referencialaboratóriumokban a HPLC-kapilláris elektroforézis vagy HPLC-tömegspektrometriás készülékeket. A referencialaboratóriumokban mosott és lizált vérmintákban levő hemoglobint endoproteinázzal bontják, a keletkező glikált hexapeptidek arányát pedig megmérik. Ezek a minták azok a kontrollok, amelyekhez világszerte a mérési eredményeket viszonyítják, az egyes eljárásokat és készülékeket beállítják. (Részleteket lásd: http://www.ngsp.org/bground.asp honlapon.)

Mivel a módszerek eredményét mmol mennyiségben megadott referens anyaghoz viszonyítják, ezért bevezették a mmol/mol mértékegységet. Azaz: a $\mathrm{HbA}_{\mathrm{lc}}$ értékét $\mathrm{mmol} / \mathrm{mol}$-ban adja meg a labor. Mivel azonban a klinikusok a százalékos értéket használják, a mmol/mol érték alapján kiszámolják a százalékos értéket is, így általában ez (is) szerepel a leleten [4].

\section{Milyen információt adhat az eredmény?}

A $\mathrm{HbA}_{\mathrm{lc}}$-szint ismerete elsősorban az antidiabetikus terápia monitorozásakor segít (1. táblázat). Általánosságban diabetesben terápiás célértékként a $7 \%$ alatti $\mathrm{HbA}_{1 \mathrm{c}}$-szintet javasolnak. 8\% feletti értékek esetén mindenképpen megfontolandó a terápiamódosítás. A célérték azonban betegenként eltérő. Alacsonyabb kell legyen hosszabb életkilátás, kevésbé intenzív terápia esetén. Rosszabb általános állapot, hypoglykaemiás hajlam, gyermek- és serdülőkor, előrehaladott érszövődmények esetén magasabb a célérték. Fontos tudni, hogy nagyon alacsony $(<4 \%)$ érték esetén igen gyakoriak a hypoglykaemiás epizódok, illetve nő a macrovascularis szövődmények kockázata. Idős betegeknél ez különösen veszélyes lehet. Számos vizsgálat például kapcsolatot mutatott ki az alacsonyabb $\mathrm{HbA}_{\mathrm{lc}_{\mathrm{c}}}$-szint és a hypoglykaemiás epizódok, illetve a feltehetően ezeknek tulajdonítható kognitív funkcióromlás vagy az elesések gyakorisága között [5].

A javasolt mérési gyakoriság stabil állapotú diabeteses betegeknél évi 2 alkalom, ha rossz a diabeteskontroll vagy ha gyógyszerváltás történt, akkor ennél gyakoribb (maximum négyet támogat az $\mathrm{OEP}$ ). Kórházi kezelés esetén - amennyiben a korábbi 3 hónapról nincs eredmény - mérni kell diabeteses betegnél.

A $\mathrm{HbA}_{1 \mathrm{c}}$-szint esetében klinikailag szignifikáns a változás, ha 0,5\%-os (abszolút százalékérték) eltérés két egymást követő mintából. Ennek feltétele: az azonos mintákból történő ismételt mérések esetén a kapott eredmények között a relatív szórás $(\mathrm{CV} \%)$ a laboratóriumon belül <3\%, a laboratóriumok között különböző módszerek esetében $<5 \%$, egy módszer esetében $<3 \%$ [2]. A 3 hónaposnál gyakoribb $\mathrm{HbA}_{1 \mathrm{c}}$-mérés (habár az OEP nem támogatja) a közelmúltban bekövetkezett változásokra is adhat valamelyes tájékoztatást [6]. A keringő (glikált és nem glikált) hemoglobin mintegy fele ugyanis 1 hónapon belül keletkezik, ezért az anyagcsere akut változása már az egy hónappal később mért $\mathrm{HbA}_{\mathrm{lc}^{-}}$ ben észlelhető. A $\mathrm{HbA}_{\mathrm{lc}} 40 \%$-a 31-90. napi és $10 \%$-a a 91-120. napi glükózkoncentráció eredményeként jön létre.

A $\mathrm{HbA}_{\mathrm{lc}}$ alapján becsülhető az elmúlt 3 hónapban az átlagos glükózszint (estimated average glucose - eAG érték; eAG (mmol/liter) = 1,59X-2,59, ahol az X a $\mathrm{HbA}_{\mathrm{lc}}$ érték százalékban) [7]. A kapcsolat azonban etnikumtól és rassztól függ; afroamerikaiaknál, hispánoknál és ázsiaiaknál például adott glykaemiás expozíció mellett magasabb a $\mathrm{HbA}_{\mathrm{lc}}$-szint [8]. Bár nem teljesen egyértelmú még ennek az információnak a klinikai értéke, egyes laboratóriumok kiszámolják és megadják.

2010-ben az American Diabetes Association, 2011ben a World Health Organization engedélyezte a $\mathrm{HbA}_{\mathrm{lc}}$ mérését a cukorbetegség diagnosztizálására. Az ajánlások szerint a vágóérték 2-es típusú diabetes esetén a $\mathrm{HbA}_{\mathrm{lc}} 6,5 \%$-os értéke [9].

A $\mathrm{HbA}_{\mathrm{lc}}$-mérésnek a glükózszint-meghatározással szemben vannak előnyei: a mintavétel után a $\mathrm{HbA}_{\mathrm{lc}}$ stabil (szemben a kémcsőben órák alatt csökkenő glükózszinttel); ugyanattól a betegtől az egymást követő napokon közel azonos $\mathrm{HbA}_{\mathrm{lc}}$-értékek mérhetők (szemben a 10-15\%-ban ingadozó éhomi vércukortól); nem befolyásolja a stressz, a napszak vagy a mintavétel előtti étkezés [8].

A diabetes valószínúsége $5,8 \%$ alatti értékek esetén alacsony, 6,5\% feletti értékek esetén definitív diabetes áll fenn; 5,8 és $6,4 \%$ között folyamatosan nő a betegség esé-

1. táblázat $\mid \mathrm{HbA}_{\mathrm{lc}}$ döntési határok

\begin{tabular}{|c|c|c|c|}
\hline Standard interpretáció & & & Százalékos érték \\
\hline Egészséges referenciatartomány & & & $4-6$ \\
\hline \multirow[t]{5}{*}{ Döntési határok } & Terápia monitorozása & Célérték & 7 \\
\hline & Terápia változtatása & $\begin{array}{l}\text { Változtatás mindenképpen } \\
\text { szükséges }\end{array}$ & 8 \\
\hline & Diagnózis & Alacsony kockázat & $<5,8$ \\
\hline & & Későbbi diabetes kockázata nő & $5,8-6,4$ \\
\hline & & Cukorbetegség & $\geq 6,5$ \\
\hline
\end{tabular}


lye (1. táblázat). A HbA $\mathrm{lc}_{\mathrm{c}}$ diagnosztikus értékével kapcsolatban azonban számos bizonytalanság van. Csak néhány ezek közül: Biztosan minden csoportban ugyanazok a vágóértékek? Mi a jelentősége az átmeneti tartománynak? Egyéb (kór)állapotok befolyásoló hatása? Hogyan változnak az eddigi besorolási határok (IGT, praediabetes)? Hogyan viszonyul a $\mathrm{HbA}_{\mathrm{lc}}$ az OGTT eredményéhez?

A $\mathrm{HbA}_{\mathrm{lc}}$-eredmény alapján a diabetes diagnózisa nem állítható fel akkor, ha a vörösvérsejtek speciális tulajdonságai, megváltozott élettartama vagy a mérést zavaró egyéb betegségek fennállása miatt a mérési eredmény nem megbízható. A $\mathrm{HbA}_{1 \mathrm{c}}$-mérés laboratóriumban, ne POCT-készüléken történjen, standardizált mérőmódszerrel.

Vannak adatok arra, hogy a $\mathrm{HbA}_{\mathrm{lc}}$ a diabeteskockázat előrejelzésére is használható. Egy amerikai felmérésben több mint 12 ezer olyan nem diabeteses veterán vett részt, akinek a kezdeti időszakban $<6,5 \%$ volt a $\mathrm{HbA}_{1 c^{-}}$ szintje. Az átlagosan 4,4 éves utánkövetés során $26,9 \%$-uknál alakult ki diabetes. A kezdetben $\geq 5,0 \%$-os $\mathrm{HbA}_{\mathrm{lc}}$-érték esetén már kimutatható volt a kockázatemelkedés: a 4,5\%-nál kisebb $\mathrm{HbA}_{\mathrm{lc}}$-szintekhez képest az 5,0-5,4\%-os $\mathrm{HbA}_{1 \mathrm{c}}$-szint mellett 1,70-szeres, 5,5$5,9 \%$ mellett 4,87-szoros, illetve $6,0-6,4 \%$ mellett 16,06-szoros volt az újonnan bekövetkező diabetes kockázata [10].

\section{$\mathrm{HbA}_{1 \mathrm{c}}$-eredményt befolyásoló preanalitikai tényezők}

A $\mathrm{HbA}_{\mathrm{lc}}$-szintet a hemoglobin mennyisége és típusa alapvetően befolyásolja (2. táblázat). Módszertől függetlenül nő a szint akkor, ha a vörösvérsejtek élettartama nő (például vashiányos anaemia esetén), illetve csökken, ha a vörösvérsejtek gyorsabban pusztulnak (például hemolitikus anaemia). A hemoglobinvariánsok típustól és relatív mennyiségüktől függően zavarhatják a meghatározást. Akut/krónikus vérvesztés, illetve transzfúzió esetén sem értékelhető a $\mathrm{HbA}_{\mathrm{lc}}$-szint. Súlyos veseelégtelenségben az anaemia, illetve a magas karbamidszint hemoglobint módosító hatása egyaránt változtathatja a $\mathrm{HbA}_{\mathrm{lc}}$ értékét (2. és 3. táblázat). Bizonyos mérések esetében a C- és E-vitamin szedése csökkentheti a mért értéket.

A vizsgálat ismétlendő (lehetőleg másik módszerrel), amennyiben a klinikai képpel nem egyeztethetö össze az eredmény. $\mathrm{HbA}_{\mathrm{lc}}$-értéket befolyásoló kórképek esetén inkább ne kerüljön sor a vizsgálatra, helyette a szérumban keringő glikált fehérjék (albumin) szintjének a mérése, azaz a fruktózamin-szint meghatározása javasolt.

\section{Következtetés}

A diabeteses betegek gondozása, állapotuk monitorozása napjainkban nem képzelhető el a $\mathrm{HbA}_{\mathrm{lc}}$-szint rend-
2. táblázat | $\mathrm{HbA}_{1 \mathrm{c}}$-szintet befolyásoló betegségek és állapotok

\begin{tabular}{ll}
\hline Emelkedést okoz & Csökkenést okoz \\
\hline Hypertriglyceridaemia (HPLC) & HbC, HbS \\
Hyperbilirubinaemia (HPLC) & E/C vitamin (módszerfüggő \\
Aszpirin & módon) \\
Uraemia & Hemolitikus anaemiák \\
Aplasztikus anaemia & Terhesség \\
Splenectomia & Akut/krónikus vérvesztés \\
Életkor (10 évente 0,1\%) & Súlyos nephropathia \\
Etnikum & Májbetegség \\
& Dialízis \\
& Malária \\
\hline
\end{tabular}

3. táblázat

Betegségek és állapotok, amelyekben a $\mathrm{HbA}_{\mathrm{lc}}$ szintje nem tükrözi feltétlenül pontosan a glykaemiás állapotot, ezért ilyen esetekben a $\mathrm{HbA}_{1 \mathrm{c}}$ nem alkalmas a diabetes kimutatására

\author{
Terhesség \\ 1-es típusú diabetes \\ Friss diabetes \\ Akut pancreasbetegség \\ Gyógyszer indukálta hyperglykaemia \\ Haemoglobinopathiák \\ Splenectomia \\ Súlyos anaemia \\ Veseelégtelenség (módszerfüggő az interferencia) \\ Májelégtelenség \\ Dialízis
}

HIV-fertőzés

szeres meghatározása nélkül. A $\mathrm{HbA}_{\mathrm{lc}}$ ezentúl bizonyos feltételek mellett a diabetes diagnosztikájában is segíthet. A különböző eszközökkel különböző laboratóriumokban mért eredmények napjainkban, a standardizációs törekvéseknek köszönhetően, összehasonlíthatók, klinikai döntéshozatalra használhatók. Ennek azonban feltétele, hogy a vizsgálatot kérő orvos tudja: egyes kórállapotok (vizsgálati módszertől függő mértékben) zavarhatják a meghatározást. A $\mathrm{HbA}_{\mathrm{lc}}$-szintet különösen kritikusan kell értékelni a haemoglobinopathiában szenvedő betegeknél, illetve azoknál, akiknél a vörösvérsejtek átlagos életideje megváltozik.

Anyagi támogatás: A közlemény megírása anyagi támogatásban nem részesült.

A szerző a cikk végleges változatát elolvasta és jóváhagyta.

Érdekeltségek: A szerzőnek a témában nincs érdekeltsége. 


\section{Irodalom}

[1] Kilpatrick, E. S., Rigby, A. S., Atkin, A. L.: AlC variability and the risk of microvascular complications in type 1 diabetes data from the Diabetes Control and Complications Trial. Diabetes Care, 2008, 31(11), 2198-2202.

[2] Weykamp, C., John, W. G., Mosca, A.: Review of the challenge in measuring hemoglobin Alc. J. Diabetes Sci. Technol., 2009, $3(3), 439-445$

[3] Weykamp, C.: HbAlc: a review of analytical and clinical aspects Ann. Lab. Med., 2013, 33(6), 393-400.

[4] Bekö, G.: Introducing the new laboratory standard for $\mathrm{HbA}_{\mathrm{lc}}$ de termination in Hungary. [A $\mathrm{HbA}_{\mathrm{lc}}$ mérésének új nemzetközi standardizációja hazánkban is bevezetésre kerül.] Orv. Hetil., 2011, 152(14), 555-558. [Hungarian]

[5] Abdelhafiz, A. H., Rodriguez-Mañas, L., Morley, J. E., et al.: Hypoglycemia in older people - a less well recognized risk factor for frailty. Aging Dis., 2015, 6(2), 156-167.

[6] Tahara, $\Upsilon$., Shima, K.: Kinetics of $\mathrm{HbA}_{1 \mathrm{c}}$, glycated albumin, and fructosamine and analysis of their weight functions against pre- ceding plasma glucose level. Diabetes Care, 1995, 18(4), 440447.

[7] Nathan, D. M., Kuenen, J., Borg, R., et al.: Translating the AlC assay into estimated average glucose values. Diabetes Care, 2008, 31(8), 1473-1478.

[8] Herman, W. H., Fajans, S. S.: Hemoglobin Alc for the diagnosis of diabetes: practical considerations. Pol. Arch. Med. Wewn., 2010, 120(1-2), 37-40.

[9] Ang, S. H., Thevarajah, M., Alias, ., et al.: Current aspects in hemoglobin Alc detection: a review. Clin. Chim. Acta, 2015, 439, 202-211.

[10] Cheng, P., Neugaard, B., Foulis, P., et al.: Hemoglobin Alc as a predictor of incident diabetes. Diabetes Care, 2011, 34(3), 610615 .

(Vásárhelyi Barna dr., Budapest, Nagyvárad tér 4., 14. emelet, 1089 e-mail: vasarhelyi.barna@med.semmelweis-univ.hu)

\section{FELHÍVÁS \\ folyóirat-referátumok beküldésére}

A Semmelweis Egyetem Továbbképző Központjának döntése értelmében

2016. január 1-jétöl folyamatosan orvos-továbbképzési pontokat kaphatnak a nemzetközi, impaktfaktoros folyóiratokban megjelent közlemények rövid összefoglalásának, referátumának beküldöi.

Az Orvosi Hetilap hasábjain megjelenő és közlésre elfogadott referátum után 1 pont, félévente maximum 12 továbbképzési pont gyüjthető, amelyet félévente összesítve továbbitunk a továbbképzési központok felé.

Távoktatással szerzett pontokból évente legfeljebb 20 pont számitható be.

Aki továbbképzési pontot kiván gyüjteni, a referátum beküldésekor adja meg pecsétszámát.

Várjuk lelkes, továbbképzési pontokat gyüjteni kivánó referálóink jelentkezését!

\section{A referátum fejlécében az alábbi adatokat kérjük megadni:}

A cikk címe magyarul, zárójelben az angol cím

A szerző(k) neve (vezetéknév, a keresztnevet jelölő betü(k) - 3 szerzőig, háromnál több szerző esetén et al.), a levelező szerző neve, munkahelye és e-mail címe)

A folyóirat neve - a szokásos nemzetközi rövidítés szerint (PubMed), évszám, kötetszám, füzetszám, a cikk kezdő és utolsó oldalszáma

A referátumot elektronikus úton (Editorial Manager vagy e-mail: edit.budai@akademiai.hu) kérjük elküldeni. 